\title{
Polymer Composites Reinforced with Natural Fibers and Nanocellulose in the Automotive Industry: A Short Review
}

\author{
Filipe V. Ferreira ${ }^{1, *(D)}$, Ivanei F. Pinheiro ${ }^{1}$, Sivoney F. de Souza ${ }^{2}$, Lucia H. I. Mei ${ }^{1}$ and \\ Liliane M. F. Lona ${ }^{1}$ \\ 1 School of Chemical Engineering, University of Campinas (UNICAMP), Campinas, SP 13083-870, Brazil; \\ ivaneipinheiro@gmail.com (I.F.P.); lumei@feq.unicamp.br (L.H.I.M.); lona@unicamp.br (L.M.F.L.) \\ 2 Wall am kiez 1, 14467 Potsdam, Germany; sivoneyfds@gmail.com \\ * Correspondence: filipevargasf@gmail.com
}

Received: 8 April 2019; Accepted: 6 May 2019; Published: 13 May 2019

\begin{abstract}
Environmental concerns and cost reduction have encouraged the use of natural fillers as reinforcement in polymer composites. Currently, a wide variety of reinforcement, such as natural fibers and nanocellulose, are used for this purpose. Composite materials with natural fillers have not only met the environmental appeal, but also contribute to developing low-density materials with improved properties. The production of natural fillers is unlimited around the world, and many species are still to be discovered. Their processing is considered beneficial since the natural fillers do not cause corrosion or great wear of the equipment. For these reasons, polymer reinforced with natural fillers has been considered a good alternative for obtaining ecofriendly materials for several applications, including the automotive industry. This review explores the use of natural fillers (natural fibers, cellulose nanocrystals, and nanofibrillated cellulose) as reinforcement in polymer composites for the automotive industry.
\end{abstract}

Keywords: natural fillers; polymer composites; industry applications

\section{Introduction}

In recent years, synthetic materials have played a key role in various industrial sectors of technology such as aerospace, aeronautics, automotive, medical, sensors, computational, etc., [1-6]. Among these materials, polymers stand out because they have low density as well as good mechanical and thermal properties that make them widely applicable [7-11]. However, increased durability of these materials has raised strong concerns about the large accumulation of plastic waste in the environment [12]. Thus, the development of cleaner processes associated with the interest in environmentally friendly materials has been the focus of research around the world [13-17]. In this context, the addition of natural fillers (natural fibers, cellulose nanocrystals, and nanofibrillated cellulose) in the polymers has been a way to prepare ecofriendly composites with improved properties, minimizing the problem in relation to the residue accumulation [18-21]. Biodegradability, mechanical properties, natural abundance, and low cost are all attractive features of these fillers [22,23]. In this review, we explore the use of natural fibers and nanocellulose as reinforcing fillers in polymer composites in the automotive industry.

\section{Natural Fillers}

The use of natural fillers in composites has attracted the attention of the scientific community because they usually show improved properties when compared with neat polymers [24]. Currently, a wide variety of natural fillers are available as reinforcement for different composites, the most used being natural fibers, cellulose nanocrystals (CNC), and nanofibrillated cellulose (NFC). 
Several natural fibers have been used as reinforcement phase for different polymer matrices [25-27], as shown in Table 1 [28-37]. Among the natural fibers, the jute is currently one of the cheapest and accounts for the highest production volume [28]. More recently, researchers have observed that self-bonded natural fiber material (SNFM) is a promising alternative for preparation of composites with high performance [29].

Table 1. Main fibers used as reinforcement and their respective polymer matrices.

\begin{tabular}{ccc}
\hline Polymer Matrix & Fiber & Reference \\
\hline PP & Sisal & {$[26,27]$} \\
PP & Bamboo & {$[28]$} \\
PP & Coconut & {$[29]$} \\
PP & Sugarcane bagasse & {$[30]$} \\
PS & Sisal & {$[31]$} \\
HDPE & Flax & {$[32,33]$} \\
LLDPE & Palm & {$[34]$} \\
Epoxy & Kenaf & {$[35]$} \\
Epoxy & Jute & {$[36]$} \\
PBS & Coconut & {$[37]$} \\
\hline
\end{tabular}

\subsection{Chemical Composition of Natural Fibers}

Natural vegetable fibers have cellulose, hemicellulose, and lignin as the main constituents, while pectin, grease, and inorganic portions can be found in lesser amounts [38-42]. Unlike synthetic fibers, the percentage of the chemical components of the natural fibers can vary according to their species and influence the fibers' properties [43]. Cellulose is the main chemical component in natural fibers, followed by hemicellulose and lignin. Table 2 shows the percentages of the chemical composition of the main fibers used as reinforcement in composites [44,45].

Table 2. Chemical composition of natural fibers. Adapted from Reference [38] with the permission of Elsevier.

\begin{tabular}{ccccc}
\hline Fiber & Cellulose (\%) & Hemicelulose (\%) & Lignin (\%) & Waxes (\%) \\
\hline Sugarcane bagasse & 45 & 30 & 24 & 1 \\
Bamboo & $26-43$ & 30 & $21-31$ & - \\
Flax & 71 & $18.6-20.6$ & 22 & 1.5 \\
Kenaf & 72 & 20.3 & 9 & - \\
Jute & $61-71$ & $14-20$ & $12-13$ & 0.5 \\
Hemp & 68 & 15 & 10 & 0.8 \\
Ramie & $68.6-76.2$ & $13-16$ & $0.6-0.7$ & 0.3 \\
Sisal & 65 & 12 & 9.9 & 2 \\
Coir & $32-43$ & $0.15-0.25$ & $40-45$ & - \\
Pineapple leaf fiber & 81 & - & 12.7 & - \\
Curaua & 73.6 & 9.9 & 7.5 & - \\
\hline
\end{tabular}

The components of natural fibers have different functions. Cellulose fibrils act as reinforcement, while lignin and hemicellulose have the role of matrix [46]. The cellulose is a homopolymer formed by repetitive units of D-glucose residues linked by $\beta-1,4$-glycosidic bonds in a syndiotatic configuration $[23,47]$. This polysaccharide is the main one responsible for the crystallinity of the natural fibers and can be classified into four different types: Cellulose I, II, III, and IV [48-50]. Hemicellulose is formed by a variety of polymerized monosaccharides, with xylose being the most abundant. The hemicellulose polymers are branched, amorphous, and are directly connected to cellulose by hydrogen bonds [51]. Due to its chain being rich in hydroxyl groups, the hemicellulose is highly hygroscopic and the removal of this polysaccharide decreases the water absorption of natural fibers [52]. Lignin is considered to be a polyphenol bonded by ether linkages, with highly branched, hydrophobic, 
and complex structures. This amorphous material consists of phenylpropane units and is responsible for keeping the cellulose fibrils bound together [51].

\subsection{Cellulose Nanocrystals (CNCs)}

Cellulose nanocrystals are rod-like particles measuring 5-50 nm in diameter and 100-3000 nm in length [23]. CNCs can be isolated from natural fibers such as jute (Corchorus capsularis), coconut (Cocos nucifera), sugarcane bagasse (Saccharum officinarum L.), Ramie (Boehmeria nivea), etc. [53,54]. The isolation process of CNCs basically consists of two stages. The first refers to the removal of non-cellulosic components such as lignin, hemicellulose, and extractives, while the second is related to isolation of CNCs by acid hydrolysis [55] (Figure 1).

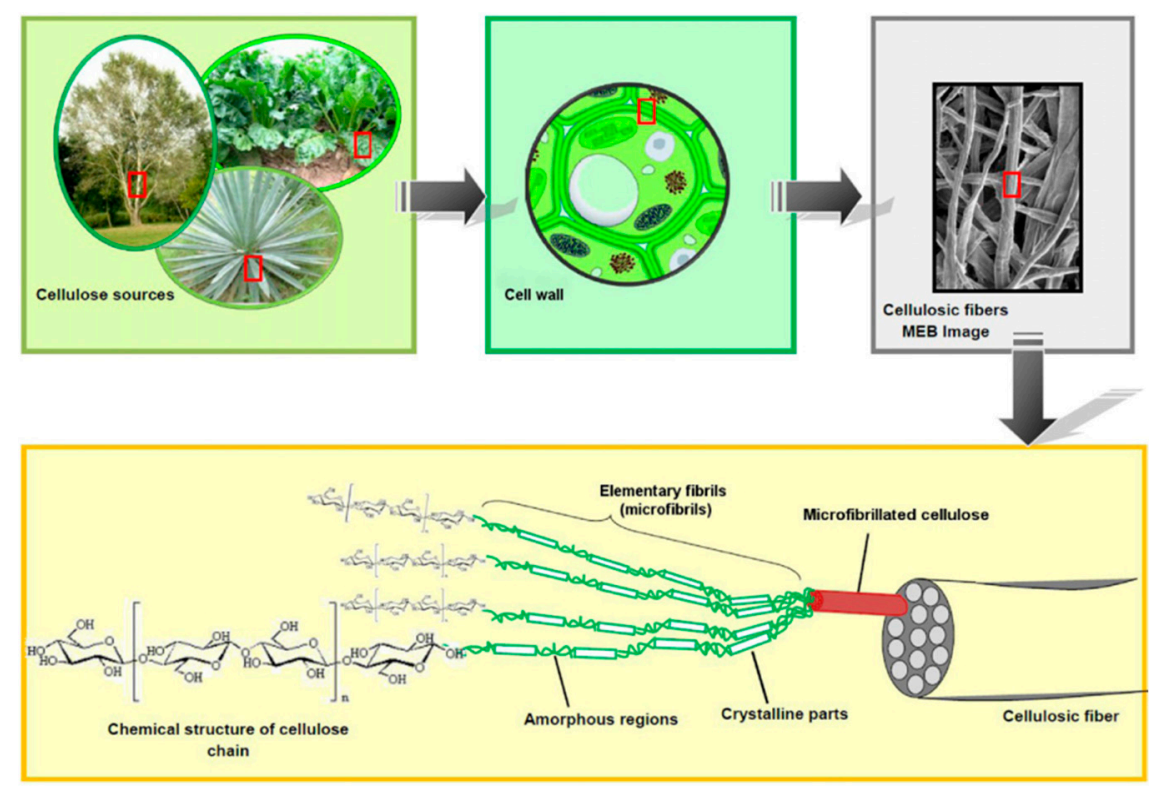

Figure 1. Deconstruction of chemical structure of cellulose sources. Reprinted from reference [48] with permission from Elsevier.

Mercerizing (or alkaline treatment) is probably the most commonly used chemical method in the treatment of natural fibers [56]. However, high concentrations of oxidant can also decrease the amount of cellulose (and crystallinity) in the final product [57]. The treatment is carried out using aqueous sodium hydroxide solution $(\mathrm{NaOH})$ in concentrations between $10 \%$ and $30 \%$, promoting good effects on the properties of the fibers [58]. After that, the bleaching method is used to purify the cellulose and can be performed with sodium chlorite $\left(\mathrm{NaClO}_{2}\right)$ or hydrogen peroxide $\left(\mathrm{H}_{2} \mathrm{O}_{2}\right)[59,60]$. Besides leading the discoloration of the fiber, the bleaching also has the purpose of removing the organic waste. A scheme of the removal of lignin and hemicellulose is shown in Figure 2 by treatment with alkaline peroxide.
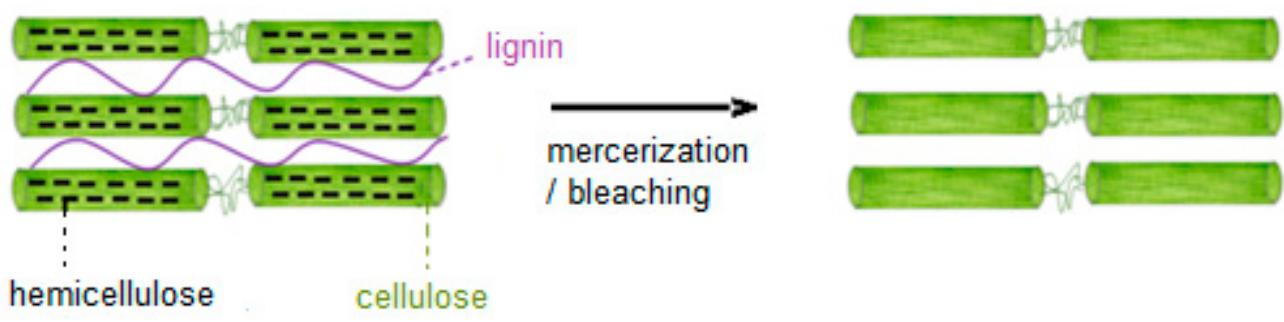

Figure 2. Representative diagram of the purification of natural fiber by alkaline peroxide. 
The second stage of CNCs isolation consists of acid hydrolysis [61]. Cellulose has amorphous regions interspersed by the crystalline domains [62]. This amorphous region is more susceptible to acid hydrolysis, facilitating the isolation of crystalline cellulose during the process [63]. The individual crystals are needle shape and known as cellulose nanocrystals [64]. After the hydrolysis, the obtained suspension is centrifuged by successive cycles, and in each cycle the residual water is replaced by

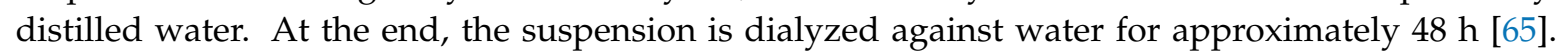
Various acids may be used for the isolation of CNCs, such as hydrochloric [66], phosphoric [67], formic [68], and sulfuric [69], and different acids can lead to different CNCs, as observed in Figure 3. Sulfuric acid is generally used during the CNCs preparation because this acid generates more stable suspensions [68]. During the hydrolysis, an esterification process occurs between the various sulfate and hydroxyl groups, generating sulfonated ester groups $\left(-\mathrm{OSO}_{3}\right)$ [70]. These groups lead to improved stable suspensions. On the other hand, these sulfonated groups can also compromise the thermal stability of the nanocrystal, because the sulfur catalyzes the dehydration and depolymerization of the cellulose [71].
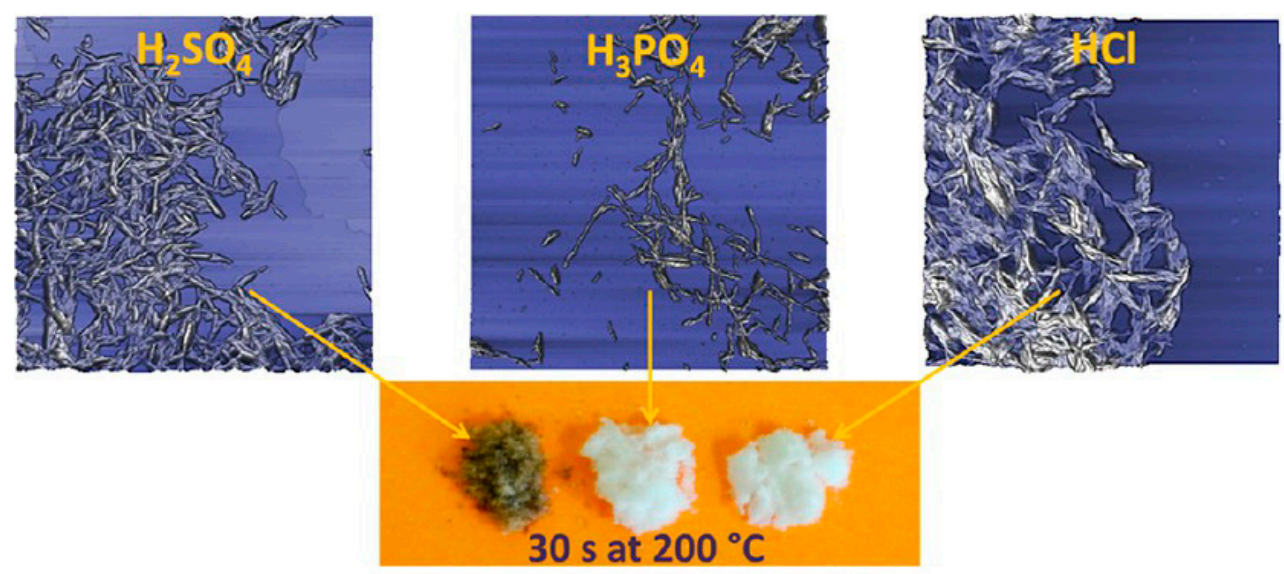

Figure 3. Schematic diagram of isolated CNCs by different acids. Reprinted from reference [67]. Copyright, 2013 American Chemical Society.

The reaction time is one of the most important parameters in obtaining nanocrystals [72,73]. The crystallinity degree of CNCs is directly influenced by this variable [68]. The longer acid/cellulose contact time leads to greater removal of the amorphous regions present in the sample. However, long reactions can degrade cellulose or even break it down into its precursor sugars. Short reaction times are not enough to obtain nanocrystals [74]. Chen et al. [75] studied the influence of reaction time on the dimensions of nanocrystals and found that as the reaction time increases the length and diameter of the CNCs decrease. According to the authors, longer times are detrimental to crystallinity. On the other hand, Lu and Hsieh [76] reported that the increase in the hydrolysis time provides an increase in the crystallinity index of the nanocrystals. This leads us to conclude that there is no standard time for hydrolysis, and each material has a unique characteristic. Figure 4 shows an illustrative scheme of the isolation of nanocrystals from bleached cellulose.
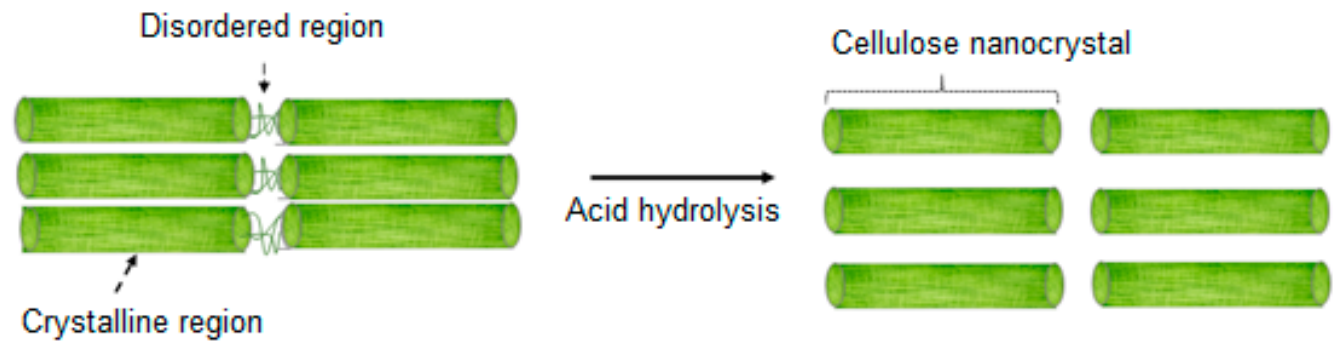

Figure 4. Scheme of isolation of cellulose nanocrystals by acid hydrolysis. 
Cellulose nanocrystals are part of a new trend for the reinforcement of polymer matrices [77]. Properties such as good mechanical properties, biodegradability, and high surface area are some attractive features for the use of CNCs as reinforcement [78,79]. Nanocomposites reinforced with CNCs usually show improved properties such as higher barrier properties, biodegradability, thermal, and mechanical properties when compared to pure polymers $[80,81]$. One of the restrictions on the use of cellulose nanocrystals is their poor compatibility with hydrophobic matrices due to their hydrophilic character [63]. However, the presence of hydroxyl groups on the surface makes the CNCs suitable for chemical modifications. Surface modification of CNCs is not discussed here because this topic has already been reviewed by other authors [82-84].

\subsection{Nanofibrillated Cellulose}

Nanofibrillated Cellulose (NFC) has outstanding properties, being applied as mechanical reinforcement due to its peculiar morphology that combines properties on the nano- and micro-scales [85]. The NFC diameter is in the nanoscale, while its length can reach some micrometers [86-88]. Basically, NFC can be obtained by a combination of different operations through the breaking down of the hierarchical cellulose structure [89]. The lignocellulosic source must be processed through different pre-treatments such as chemical (pulping, bleaching reactions, and chemical modifications) or enzymatic, with the aim of exposing the cellulose content. Other methods combine enzymatic hydrolysis with mechanical shearing [90]. In this case, the enzyme can act on the fibrillation by decreasing the energy necessary during the process. Figure 5 shows the combination of different operations to produce NFC [89].

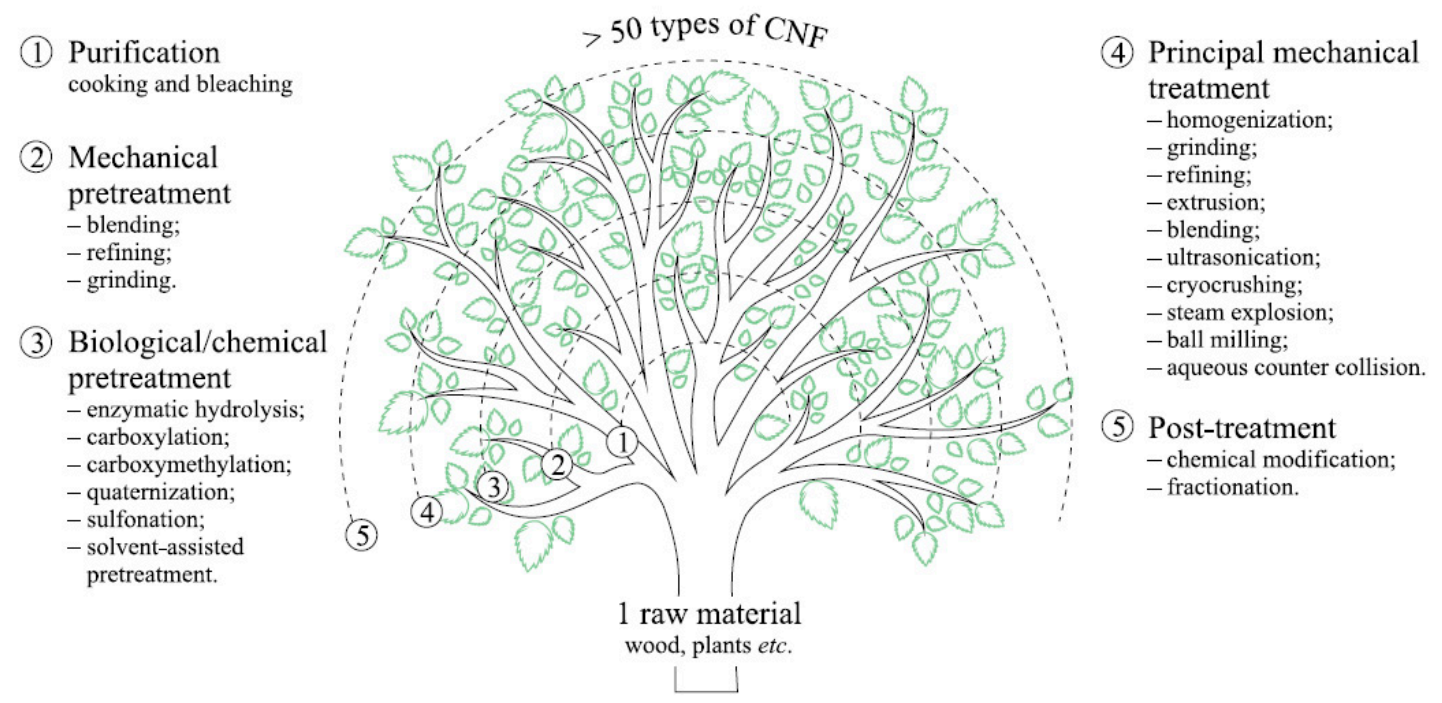

Figure 5. Production process of Nanofibrillated Cellulose (NFC): combination of different operations. Reproduced from reference [89] with the permission of Elsevier.

NFC presents crystalline and amorphous regions [85] and has a morphology of a network with lots of entanglement points (Figure 6a) [91,92]. Consequently, the NFC material has more flexibility than CNCs, which allows for more elongation during any mechanical strain. According to De France et al. [93], NFCs are longer and have lower crystallinity compared to CNCs, making them capable of building an entangled network even in lower concentrations. The end properties of NFCs depend basically on the process used to release them from cellulose, such as the kind of equipment used, the energy consumption or number of cycles, pressure, and even the pre-treatment to isolate the cellulose (Figure 6b) [94]. Some equipment can be used to produce NFC and the most common are: grinders, a high-pressure homogenizer, and a micro fluidizer capable of promoting a 
shear along the fibers' axis. The mechanical properties can be tailored according to the manipulation of the machine parameters used during the fabrication [95].
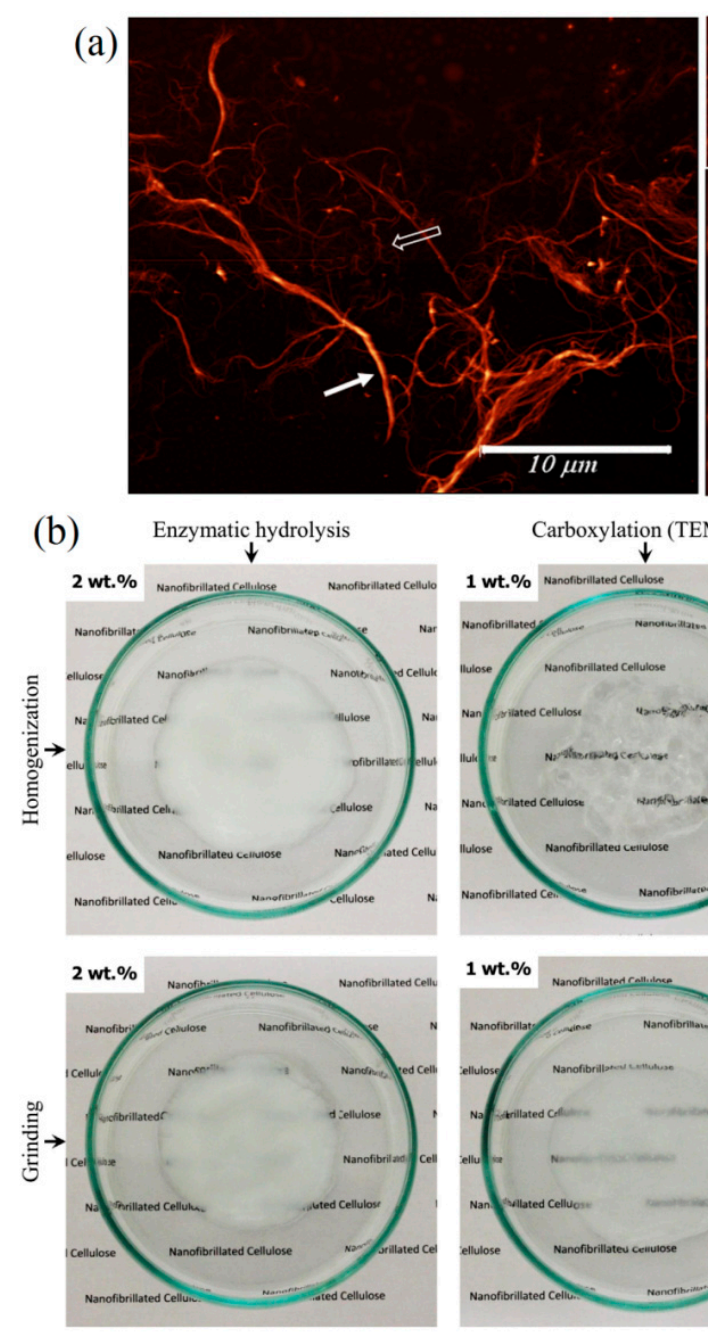
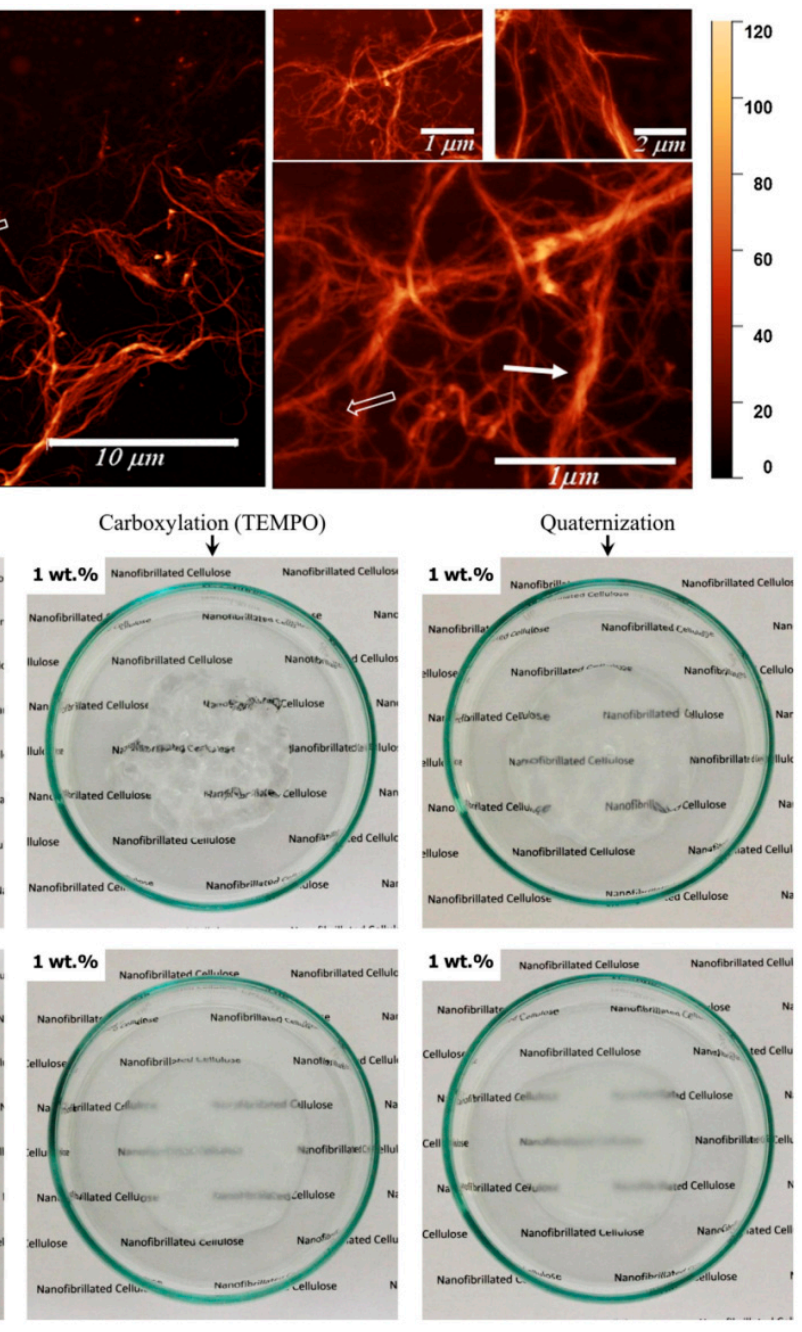

Figure 6. (a) AFM images of NFCs. (b) Top view images of NFC suspensions placed in Petri dishes produced using different processing conditions. Reprinted from reference (a) [92] and (b) [89] with permission from Elsevier.

The potential use of NFC as reinforcement material can be correlated to the lower-density and the higher-strength produced due to their high surface area that can interact more strongly with the matrix (compared to conventional micro reinforcements). These aspects make the NFC a very attractive material for the development of new composites [88,96,97]. In this context, a comparison of the reinforcement capacity of CNC and NFC (at the same concentrations) was evaluated using poly (ethylene oxide) (PEO) as the polymer matrix. The authors reported that the nanocomposites containing NFC exhibited higher-strength and elastic modulus than nanocomposites reinforced with CNC. On the other hand, CNC-based nanocomposites presented higher-strain of failure. The higher strength of NFC-based nanocomposites may be attributed to their high-aspect ratio of NFC that favors more entanglement and network percolation [97]. The treatments of the nanofibers, such as the purification or chemical modifications, are important for improving the reinforcement effect of the NFC because they facilitate the interaction fiber-matrix. Depending on the treatment, the cellulose chain can change its structure, surface, and composition [98]. Reviews on surface modification of NFC can be found elsewhere $[99,100]$. 
NFC are also used as a reinforcing agent for other materials [93]. Moberg et al. [101] have individually measured the reinforcement capacity of two types of NFC in hydrogels through the rheological properties. They showed that the dimensions (length or aspect ratio) and the surface modification have more influence on the rheological properties [101]. The reinforcement capacity of cellulose nanoparticles was studied in hydrogels with NFC before the mechanical shearing. Exposing the cellulose fibers to solutions with high concentrations of $\mathrm{NaOH}$ allows for changes in the crystal structure [102,103]. Boufi et al. [104] reported that the reinforcement improvement in paper production varies significantly depending on the kind of cellulose (nanofibers, nanocrystals, or cellulose nanofibrillated), the amount of NFC, raw source, and treatment [104].

\section{Reinforcement/Matrix Interface}

The matrix phase presents several functions in the composites, such as (i) keeping the fillers together, (ii) supporting a small portion of the applied tension, and (iii) distributing stresses to the fillers when an external force is applied to the composite [105]. The stress distribution in a composite is one of the most important functions because it directly influences their mechanical properties [106,107]. The adhesion and dispersion between both reinforcing and the matrix phases are required to ensure good force transfer in the composite [108]. Some theories have been used to explain adhesion in composite materials [109]. Electrostatic attraction occurs when different electrostatic charges at the reinforcement-matrix interface can lead to better adhesion by strong forces of attraction. In many cases, chemical bonding occurs by the addition of coupling agents which are able to link with compatible groups present in both reinforcement and the matrix. The adhesive resistance depends on the type and amount of bond formed. In the case of adhesion by mechanical interactions between matrices and fillers, the reinforcement should have high-surface roughness to guarantee good mechanical anchoring of the matrix, and therefore good results.

The role of reinforcement adhesion in polymer matrices is critical and generally surface modification of the filler is required to increase the filler-matrix compatibility [3]. The poor adhesion that normally occurs between natural hydrophilic fillers and hydrophobic matrices of many composites is the main reason for modification of the fillers' surface [110]. Chemical treatment is one of the most used strategies for increasing fillers' compatibility with the matrix [111-115]. However, in some cases the fillers' roughness may aid in the filler-matrix interaction and no surface treatment is needed [116].

\section{Processing of Nanocomposites Reinforced with Natural Fillers}

Recent research has been devoted to the development of methods for the production of polymeric nanocomposites based on natural fillers with homogeneous dispersion and good interaction between reinforcement and the matrix. Detailed information can be found in the works of Oksman et al. [117], Dufresne [118], Siqueira et al. [119], and Ferreira et al. [47]. Briefly, composites can be produced by three dominant techniques: casting method, melt mixing method, and in situ polymerization. Each method can produce material with a different performance. Wang et al. [120] studied the effect of preparation method on the final performance of bamboo pulp fiber (BPF)/HDPE composites. They observed that the $\mathrm{E}^{\prime}$, crystallinity index (CrI) and heat distortion temperature (HDT) vary according to the used method.

The casting method is the most widely used technique for the production of these composites [62]. The method consists of adding fillers to the polymer previously dissolved in a suitable solvent. After this step, the composite is obtained by the evaporation of the solvent. Strong interactions are achieved by using water-soluble polymers due to the nature of natural fillers [117]. Otherwise, by using hydrophobic polymers, the dispersion and the low interaction between the filler and the matrix are limiting factors of the process [121]. Despite the good results often obtained, this method is not preferred due to the use of organic solvents for hydrophobic matrices, although they are biodegradable [122]. In the case of the melt mixing method, it consists of incorporating the fillers into the molten polymer under high-shear forces, which is necessary to homogenize both phases, i.e., polymer and filler [123]. 
The main limitation of this method is related to the dispersion of the filler. As discussed above, the natural fillers tend to agglomerate in nonpolar environments due to their hydrophilic nature [124]. This agglomeration is increased with the high viscosity of many polymer matrices. In addition, the low thermal stability of the filler may be a limiting factor during the process [18]. The in situ polymerization method is a widely-used technique for the production of composites using other types of filler, such as carbon nanotube [125], but still, few studies have shown the production of composites based on natural fillers due to their low thermal stability. In the method of in situ polymerization, the filler is dispersed in the monomer phase before polymerization. Generally, the polymerization takes place at temperatures close to the degradation temperatures of the fillers (about $230{ }^{\circ} \mathrm{C}$ ), limiting its use $[118,126]$.

Due to the $\mathrm{OH}$ groups on the cellulose surface, natural fillers have a high-potential to adsorb and absorb water molecules. When the water is not removed before the process, it can affect the final performance of the material. The mechanical properties may reduce due to the difficulty of load-transfer between the matrix and reinforcement phase [127]. Chemical modifications, in general, protect the cellulose surface of the water uptake as well as improve the adhesion with the matrix [128].

Several authors have reported improvement in thermal and mechanical properties after the addition of natural fibers, NFC and CNC, into polymer matrix [88,129]. Ferreira et al. [24] prepared PBAT-based composites using three different natural fibers (Croton lanjouwensis, Malvastrum tomentosum, and Trema micrantha) from the Amazon forest via the melt mixing method. The authors observed that all composites showed greater modulus of elasticity than neat polymer and this improvement varies according to the type of fiber used as reinforcement. Fibers' crystallinity and roughness in the composites play an important role in the reinforcement mechanism. Pinheiro et al. [130] prepared PBAT-based composite reinforced with munguba fibers (Pseudobombax munguba) via the melt mixing procedure and reported an increase in the elastic modulus of the composites when compared with pure PBAT. Ferreira et al. [131] prepared low-density polyethylene (LDPE) composites reinforced with 10,20 , and $30 \mathrm{wt} . \%$ sugarcane bagasse. They observed improvement in the mechanical performance of the composites. Wang et al. [132] prepared high-strength molded fiber material with potential to be used as a substitute for plastic parts in automotive applications.

Other authors have studied the effect of NFC in the mechanical properties of PBAT. Mukherjee et al. [133] prepared PBAT composite reinforced with NFC. Transmission electron microscopy (TEM) results showed that good dispersion was achieved only in the composite with $0.2 \%$ NFC. The differential scanning calorimetry (DSC) results revealed an increase in the glass transition ( $\mathrm{T}_{\mathrm{g}}$ ) only for those composites loaded with $0.2 \%$ NFC, related to the restriction of the mobility of the polymer chain due to the good dispersion of NFC. In addition, the authors attributed the best mechanical performance of $0.2 \%$ NFC-loaded composite with the homogeneous dispersion of the filler in the polymer matrix. Composites prepared with different polymer matrices reinforced with NFC obtained from the Curaua plant (Ananas erectifolius L. B. Smith) were reported by Souza et al. [86]. The authors observed that the transparency of the polymers was maintained and that the maximum stress of composites reinforced with $4 \%$ and $5 \%$ NFC increased $36 \%$ and $44 \%$, respectively. Other authors have reported a higher-maximum strength and young modulus after the incorporation of NFC from sugar beet into phenol-formaldehyde resin [104].

The first use of CNC as a reinforcement of various polymers, including polypropylene (PP), polystyrene (PS), and high-density polyethylene (HDPE), was reported by Boldizar et al. [134]. In recent years, the number of publications relative to this system has increased exponentially [77]. Aranguren et al. [135] studied the effect of the addition of cellulose nanocrystals in the mechanical properties of polyurethane (PU). The nanocrystals were obtained from cellulose microcrystals (MCC) by the acid hydrolysis method. The polymer was produced by the mixture of polyether diol and polyol, and the nanofiller content was $0.5 ; 1 ; 5 \%$ mass. The results showed that Young's modulus and storage modulus increased with the increasing CNC content. Another composite reinforced with nanocrystals, based on Poly (vinyl alcohol) (PVA), was developed. The nanocrystals were isolated by the acid hydrolysis from microcrystalline cellulose (MCC) and used in amounts of $1 \%, 3 \%, 5 \%$, and $7 \%(\mathrm{w})$, as reported 
by Cho et al. [13]. The authors observed an increase of the elastic modulus of the materials as the reinforcement content increased, however, the modulus of elasticity decreased with the addition of $7 \%$ mass of CNC. In addition, the results of dynamic-mechanical analysis (DMA) showed a significant increase in the storage modulus of the nanocomposites prepared with $3 \%$ mass when compared to the pure polymer. Similar results were reported by other authors using $6 \%$ mass of cellulose nanocrystals as reinforcement and PVA as matrix [47]. Tan et al. [121] prepared CNC-based nanocomposites with poly (ethylene-co-vinyl acetate) matrix (EVA) and observed improvement in their mechanical properties. Other authors [136] added CNC in poly (lactic acid) (PLA) and observed that both storage modulus and loss modulus of nanocomposites were higher than pure polymer. Morelli et al. [137] observed that the addition of CNC increased the elastic modulus and tensile strength of the PBAT.

These improved properties of polymer composites reinforced with natural fillers show that these materials are potential candidates for a wide range of applications in several industrial sectors. Here we discuss the use of these materials in the automotive industry.

\section{Polymer Composites Reinforced with Natural Fillers in The Automotive Industry}

Polymer composites reinforced with natural fillers have been used to replace commonly used materials in several fields, including the automotive industry [138,139]. There are several engineering and environmental reasons why the addition of natural fillers into polymer matrix is attractive for this industry. The high strength and stiffness and also biodegradability of the fibers, combined with the sustainability trend, has led the industries to seek polymer composites reinforced with natural fillers [140-142]. Another important point to consider is the fuel-efficiency of lightweight cars, trucks, buses, aircraft, etc., made of polymer composites reinforced with natural fillers. Related to the sustainability trend, Greenpeace groups, the European Commission, and NGOs in various countries have issued guidelines for the industries to balance sustainability [143]. For these reasons, these polymer composites are continuously being developed and their application in the automotive industry has been observed [144,145]. In this context, Wu et al. [146] prepared natural fiber-based composites with suitable mechanical performance and reduced energy consumption, contributing to a more sustainable process.

A number of automotive companies have used polymer composites reinforced with natural fillers, especially in the internal parts of the car such as door panels, trim parts in dashboards, parcel shelves, etc. [147,148]. Mercedes-Benz used epoxy/jute as door panels in E-class vehicles [28], while Audi A2 used polyurethane filled with flax/sisal as door trim panels [149]. Toyota has used different polymer composites reinforced with natural fillers as spare tire covers in the RAUM 2003 model [150]. Poly (butylene succinate) reinforced with bamboo fibers was used for interior components by Mitsubishi motors' [150], and BMW used thermosetting acrylic copolymer filled with prepreg natural fiber mats for the lower door panel [151]. In exterior car parts, the weather conditions, such as humidity and temperature, are challenges for the use of the composites reinforced with natural fillers [152]. Thus, so far there are very few parts made for this purpose $[153,154]$.

\section{Perspectives}

Polymer composites reinforced with natural fillers have been used in automotive applications. However, the widespread use of these composite materials still has some thresholds, especially related to their cost of production, shorter life-cycle, and inability to control the microstructures [155]. This has led to only limited commercial success [156]. This trend can be reversed by improvement in the performance, and the environmental appeal where the use of composites with $20 \mathrm{wt} . \%$ of natural fillers, for example, allow for a reduction of at least $20 \%$ on the negative impact that non-biodegradable polymers would cause in the natural environment [157]. In sum, the market of polymer composites reinforced with natural fillers for the automotive industry is a multibillion-dollar business where manufacturers and engineers are always on the lookout for new materials to prepare a more competitive material, thereby increasing their profit margin [158]. 


\section{Conclusions}

Composites filled with natural fillers (natural fibers, cellulose nanocrystals, and nanofibrillated cellulose) have gained great focus and investment by researchers and companies due to the need for renewable, friendly materials with improved properties. A high number of natural fibers have been exploited for the development of composites, and the main fibers used are coconut (Cocos nucifera), sisal (Agave sisalana), curaua (Ananas erectifolius), and jute (Corchorus capsularis). Natural fibers have also been widely exploited to obtain cellulose nanocrystals and nanofibrillated cellulose, which are the crystalline portions of cellulose. These natural fillers have been widely used in different polymer matrices and improvements in their thermal and mechanical properties have been observed. Polymer composite reinforced with natural fillers with improved performance are a good alternative for obtaining lighter and more ecofriendly materials for the automotive industry. However, from a technical point of view, the greater use of these materials will only be achieved when the cost of production and the thermal and mechanical performance are competitive with the materials currently used. In addition, other aspects such as reproducibility and long life-cycle should be considered. Overall, the expectations are optimistic, the use of polymer composites reinforced with natural fillers in the automotive industry has great potential for reducing the huge amount of non-biodegradable waste in landfills and contributing to a more sustainable society.

Funding: This research was funded by Coordenação de Aperfeiçoamento de Pessoal de Nível Superior, Conselho Nacional de Desenvolvimento Científico e Tecnológico and Fundação de Amparo à Pesquisa do Estado de São Paulo, grant number 2016/09588-9.

Conflicts of Interest: The authors declare no conflict of interest.

\section{References}

1. Mittal, G.; Dhand, V.; Rhee, K.Y.; Park, S.-J.; Lee, W.R. A review on carbon nanotubes and graphene as fillers in reinforced polymer nanocomposites. J. Ind. Eng. Chem. 2015, 21, 11-25. [CrossRef]

2. Francisco, W.; Ferreira, F.V.; Ferreira, E.V.; Cividanes, L.D.S.; dos, R.; Coutinho, A.; Thim, G.P. Functionalization of Multi-Walled Carbon Nanotube and Mechanical Property of Epoxy-Based Nanocomposite. J. Aerosp. Technol. Manag. 2015, 7, 289-293. [CrossRef]

3. Cividanes, L.S.; Franceschi, W.; Ferreira, F.V.; Menezes, B.R.C.; Sales, R.C.M.; Thim, G.P. How Do CNT affect the branch and crosslink reactions in CNT-epoxy. Mater. Res. Express 2017, 4, 105101. [CrossRef]

4. $\quad$ Ferreira, F.V.; Mariano, M.; Lepesqueur, L.S.S.; Pinheiro, I.F.; Santos, L.G.; Burga-Sánchez, J.; Souza, D.H.S.; Koga-Ito, C.Y.; Teixeira-Neto, A.A.; Mei, L.H.I.; et al. Silver nanoparticles coated with dodecanethiol used as fillers in non-cytotoxic and antifungal PBAT surface based on nanocomposites. Mater. Sci. Eng. C 2019, 98, 800-807. [CrossRef] [PubMed]

5. Scaffaro, R.; Maio, A.; Gulino, E.F;; Megna, B. Structure-property relationship of PLA-Opuntia Ficus Indica biocomposites. Compos. Part B Eng. 2019, 167, 199-206. [CrossRef]

6. Scaffaro, R.; Maio, A. Optimization of two-step techniques engineered for the preparation of polyamide 6 graphene oxide nanocomposites. Compos. Part B Eng. 2019, 165, 55-64. [CrossRef]

7. Botan, R.; Pinheiro, I.F.; Ferreira, F.V.; Lona, L.M.F. Correlation between water absorption and mechanical properties of polyamide 6 filled with layered double hydroxides (LDH). Mater. Res. Express 2018, 5, 065004. [CrossRef]

8. de Menezes, B.R.C.; Ferreira, F.V.; Silva, B.C.; Simonetti, E.A.N.; Bastos, T.M.; Cividanes, L.S.; Thim, G.P. Effects of octadecylamine functionalization of carbon nanotubes on dispersion, polarity, and mechanical properties of CNT/HDPE nanocomposites. J. Mater. Sci. 2018, 53, 14311-14327. [CrossRef]

9. Scaffaro, R.; Maio, A.; Lopresti, F. Effect of graphene and fabrication technique on the release kinetics of carvacrol from polylactic acid. Compos. Sci. Technol. 2019, 169, 60-69. [CrossRef]

10. Scaffaro, R.; Maio, A.; Botta, L.; Gulino, E.F.; Gulli, D. Tunable release of Chlorhexidine from Polycaprolactone-based filaments containing graphene nanoplatelets. Eur. Polym. J. 2019, 110, 221-232. [CrossRef] 
11. Maio, A.; Scaffaro, R.; Lentini, L.; Palumbo Piccionello, A.; Pibiri, I. Perfluorocarbons-graphene oxide nanoplatforms as biocompatible oxygen reservoirs. Chem. Eng. J. 2018, 334, 54-65. [CrossRef]

12. Lebreton, L.C.M.; van der Zwet, J.; Damsteeg, J.-W.; Slat, B.; Andrady, A.; Reisser, J. River plastic emissions to the world's oceans. Nat. Commun. 2017, 8, 15611. [CrossRef]

13. Cho, M.J.; Park, B.D. Tensile and thermal properties of nanocellulose-reinforced poly(vinyl alcohol) nanocomposites. J. Ind. Eng. Chem. 2011, 17, 36-40. [CrossRef]

14. Scaffaro, R.; Maio, A. A green method to prepare nanosilica modified graphene oxide to inhibit nanoparticles re-aggregation during melt processing. Chem. Eng. J. 2017, 308, 1034-1047. [CrossRef]

15. Scaffaro, R.; Botta, L.; Lopresti, F.; Maio, A.; Sutera, F. Polysaccharide nanocrystals as fillers for PLA based nanocomposites. Cellulose 2017, 24, 447-478. [CrossRef]

16. Rosa, R.P.; Ferreira, F.V.; Saravia, A.P.K.; Rocco, S.A.; Sforça, M.L.; Gouveia, R.F.; Lona, L.M.F. A Combined Computational and Experimental Study on the Polymerization of $\varepsilon$-Caprolactone. Ind. Eng. Chem. Res. 2018, 57, 13387-13395. [CrossRef]

17. Scaffaro, R.; Maio, A.; Lopresti, F. Physical properties of green composites based on poly-lactic acid or Mater-Bi®filled with Posidonia Oceanica leaves. Compos. Part A Appl. Sci. Manuf. 2018, 112, 315-327. [CrossRef]

18. Ferreira, F.V.; Cividanes, L.S.; Gouveia, R.F.; Lona, L.M.F. An overview on properties and applications of poly(butylene adipate-co-terephthalate)-PBAT based composites. Polym. Eng. Sci. 2017. [CrossRef]

19. Maia, T.H.S.; Larocca, N.M.; Beatrice, C.A.G.; de Menezes, A.J.; de Freitas Siqueira, G.; Pessan, L.A.; Dufresne, A.; França, M.P.; de Almeida Lucas, A. Polyethylene cellulose nanofibrils nanocomposites. Carbohydr. Polym. 2017, 173, 50-56. [CrossRef] [PubMed]

20. Junior de Menezes, A.; Siqueira, G.; Curvelo, A.A.S.; Dufresne, A. Extrusion and characterization of functionalized cellulose whiskers reinforced polyethylene nanocomposites. Polymer (Guildf.) 2009, 50, 4552-4563. [CrossRef]

21. Dufresne, A. Nanocellulose Processing Properties and Potential Applications. Curr. For. Rep. 2019, 5, 76-89. [CrossRef]

22. Henrique, M.A.; Flauzino Neto, W.P.; Silvério, H.A.; Martins, D.F.; Gurgel, L.V.A.; da, S.; Barud, H.; de Morais, L.C.; Pasquini, D. Kinetic study of the thermal decomposition of cellulose nanocrystals with different polymorphs, cellulose I and II, extracted from different sources and using different types of acids. Ind. Crops Prod. 2015, 76, 128-140. [CrossRef]

23. Habibi, Y.; Lucia, L.A.; Rojas, O.J. Cellulose Nanocrystals: Chemistry, Self-Assembly, and Applications. Chem. Rev. 2010, 110, 3479-3500. [CrossRef] [PubMed]

24. Ferreira, F.V.; Pinheiro, I.F.; Mariano, M.; Cividanes, L.S.; Costa, J.C.M.; Nascimento, N.R.; Kimura, S.P.R.; Neto, J.C.M.; Lona, L.M.F. Environmentally friendly polymer composites based on PBAT reinforced with natural fibers from the amazon forest. Polym. Compos. 2019. [CrossRef]

25. Shao, D.; Xu, M.; Cai, L.; Shi, S.Q. Fabrication of Wood Fiber-rubber Composites with Reclaimed Rubber. BioResources 2018, 13. [CrossRef]

26. Wang, Q.; Xiao, S.; Shi, S.Q.; Cai, L. Mechanical Strength, Thermal Stability, and Hydrophobicity of Fiber Materials after Removal of Residual Lignin. BioResources 2017, 13. [CrossRef]

27. Xia, C.; Zhang, S.; Ren, H.; Shi, S.; Zhang, H.; Cai, L.; Li, J. Scalable Fabrication of Natural-Fiber Reinforced Composites with Electromagnetic Interference Shielding Properties by Incorporating Powdered Activated Carbon. Materials (Basel) 2015, 9, 10. [CrossRef] [PubMed]

28. Alves, C.; Ferrão, P.M.C.; Silva, A.J.; Reis, L.G.; Freitas, M.; Rodrigues, L.B.; Alves, D.E. Ecodesign of automotive components making use of natural jute fiber composites. J. Clean. Prod. 2010, 18, 313-327. [CrossRef]

29. Wang, Q.; Xiao, S.; Shi, S.Q.; Cai, L. Mechanical property enhancement of self-bonded natural fiber material via controlling cell wall plasticity and structure. Mater. Des. 2019, 172, 107763. [CrossRef]

30. Albano, C.; Reyes, J.; Ichazo, M.; González, J.; Brito, M.; Moronta, D. Analysis of the mechanical, thermal and morphological behaviour of polypropylene compounds with sisal fibre and wood flour, irradiated with gamma rays. Polym. Degrad. Stab. 2002, 76, 191-203. [CrossRef]

31. Mohan, T.P.; Kanny, K. Chemical treatment of sisal fiber using alkali and clay method. Compos. Part A Appl. Sci. Manuf. 2012, 43, 1989-1998. [CrossRef] 
32. Chattopadhyay, S.K.; Khandal, R.K.; Uppaluri, R.; Ghoshal, A.K. Bamboo fiber reinforced polypropylene composites and their mechanical, thermal, and morphological properties. J. Appl. Polym. Sci. 2011, 119, 1619-1626. [CrossRef]

33. Bettini, S.H.P.; Bicudo, A.B.L.C.; Augusto, I.S.; Antunes, L.A.; Morassi, P.L.; Condotta, R.; Bonse, B.C. Investigation on the use of coir fiber as alternative reinforcement in polypropylene. J. Appl. Polym. Sci. 2010, 118, 2841-2848. [CrossRef]

34. Luz, S.M.; Caldeira-Pires, A.; Ferrão, P.M.C. Environmental benefits of substituting talc by sugarcane bagasse fibers as reinforcement in polypropylene composites: Ecodesign and LCA as strategy for automotive components. Resour. Conserv. Recycl. 2010, 54, 1135-1144. [CrossRef]

35. Manikandan Nair, K.; Thomas, S.; Groeninckx, G. Thermal and dynamic mechanical analysis of polystyrene composites reinforced with short sisal fibres. Compos. Sci. Technol. 2001, 61, 2519-2529. [CrossRef]

36. Li, X.; Tabil, L.G.; Oguocha, I.N.; Panigrahi, S. Thermal diffusivity, thermal conductivity, and specific heat of flax fiber-HDPE biocomposites at processing temperatures. Compos. Sci. Technol. 2008, 68, 1753-1758. [CrossRef]

37. John, M.J.; Tlili, R.; Anandjiwala, R.D.; Boudenne, A.; Ibos, L. Effect of amphiphilic coupling agent on heat flow and dielectric properties of flax-polypropylene composites. Compos. Part B Eng. 2012, 43, 526-532. [CrossRef]

38. Shinoj, S.; Visvanathan, R.; Panigrahi, S.; Varadharaju, N. Dynamic mechanical properties of oil palm fibre (OPF)-linear low density polyethylene (LLDPE) biocomposites and study of fibre-matrix interactions. Biosyst. Eng. 2011, 109, 99-107. [CrossRef]

39. Yousif, B.F.; Shalwan, A.; Chin, C.W.; Ming, K.C. Flexural properties of treated and untreated kenaf/epoxy composites. Mater. Des. 2012, 40, 378-385. [CrossRef]

40. Ferreira, J.M.; Capela, C.; Manaia, J.; Costa, J.D. Mechanical Properties of Woven Mat Jute/Epoxy Composites. Mater. Res. 2016, 19, 702-710. [CrossRef]

41. Nam, T.H.; Ogihara, S.; Tung, N.H.; Kobayashi, S. Effect of alkali treatment on interfacial and mechanical properties of coir fiber reinforced poly(butylene succinate) biodegradable composites. Compos. Part B Eng. 2011, 42, 1648-1656. [CrossRef]

42. Faruk, O.; Bledzki, A.K.; Fink, H.-P.; Sain, M. Biocomposites reinforced with natural fibers: 2000-2010. Prog. Polym. Sci. 2012, 37, 1552-1596. [CrossRef]

43. Yamada, E.A.; Alvim, I.D.; Santucci, M.C.C.; Sgarbieri, V.C. Composição centesimal e valor protéico de levedura residual da fermentação etanólica e de seus derivados. Rev. Nutr. 2003, 16, 423-432. [CrossRef]

44. Ragauskas, A.J. The Path Forward for Biofuels and Biomaterials. Science (80-.) 2006, 311, 484-489. [CrossRef]

45. Sluiter, J.B.; Chum, H.; Gomes, A.C.; Tavares, R.P.A.; Azevedo, V.; Pimenta, M.T.B.; Rabelo, S.C.; Marabezi, K.; Curvelo, A.A.S.; Alves, A.R.; et al. Evaluation of Brazilian Sugarcane Bagasse Characterization: An Interlaboratory Comparison Study. J. AOAC Int. 2016, 99, 579-585. [CrossRef] [PubMed]

46. Festucci-Buselli, R.A.; Otoni, W.C.; Joshi, C.P. Structure, organization, and functions of cellulose synthase complexes in higher plants. Braz. J. Plant Physiol. 2007, 19, 1-13. [CrossRef]

47. Ferreira, F.V.; Pinheiro, I.F.; Gouveia, R.F.; Thim, G.P.; Lona, L.M.F. Functionalized cellulose nanocrystals as reinforcement in biodeg radable polymer nanocomposites. Polym. Compos. 2017. [CrossRef]

48. Lavoine, N.; Desloges, I.; Dufresne, A.; Bras, J. Microfibrillated cellulose-Its barrier properties and applications in cellulosic materials: A review. Carbohydr. Polym. 2012, 90, 735-764. [CrossRef] [PubMed]

49. Moon, R.J.; Martini, A.; Nairn, J.; Simonsen, J.; Youngblood, J. Cellulose nanomaterials review: Structure, properties and nanocomposites. Chem. Soc. Rev. 2011, 40, 3941-3994. [CrossRef]

50. Langan, P.; Nishiyama, Y.; Chanzy, H. X-ray Structure of Mercerized Cellulose II at $1 \AA$ Resolution. Biomacromolecules 2001, 2, 410-416. [CrossRef] [PubMed]

51. Silva, R.; Haraguchi, S.K.; Muniz, E.C.; Rubira, A.F. Aplicações de fibras lignocelulósicas na química de polímeros e em compósitos. Quim. Nova 2009, 32, 661-671. [CrossRef]

52. Ben Sghaier, A.E.O.; Chaabouni, Y.; Msahli, S.; Sakli, F. Morphological and crystalline characterization of $\mathrm{NaOH}$ and $\mathrm{NaOCl}$ treated Agave americana L. fiber. Ind. Crops Prod. 2012, 36, 257-266. [CrossRef]

53. Garcia de Rodriguez, N.L.; Thielemans, W.; Dufresne, A. Sisal cellulose whiskers reinforced polyvinyl acetate nanocomposites. Cellulose 2006, 13, 261-270. [CrossRef]

54. Dufresne, A. Nanocellulose: From Nature to High Performance Tailored Materials; Walter de Gruyter: Berlin, Germany, 2013; ISBN 978-3-11-025456-3. 
55. Ferreira, F.V.; Mariano, M.; Rabelo, S.C.; Gouveia, R.F.; Lona, L.M.F. Isolation and surface modification of cellulose nanocrystals from sugarcane bagasse waste: From a micro- to a nano-scale view. Appl. Surf. Sci. 2018, 436, 1113-1122. [CrossRef]

56. John, M.J.; Anandjiwala, R.D. Recent developments in chemical modification and characterization of natural fiber-reinforced composites. Polym. Compos. 2008, 29, 187-207. [CrossRef]

57. Kargarzadeh, H.; Ahmad, I.; Abdullah, I.; Dufresne, A.; Zainudin, S.Y.; Sheltami, R.M. Effects of hydrolysis conditions on the morphology, crystallinity, and thermal stability of cellulose nanocrystals extracted from kenaf bast fibers. Cellulose 2012, 19, 855-866. [CrossRef]

58. Sreekala, M.S. Oil Palm Fibre Reinforced Phenol Formaldehyde Composites: Influence of Fibre Surface Modifications on the Mechanical Performance. Appl. Compos. Mater. 2000, 7, 295-329. [CrossRef]

59. Rout, J.; Misra, M.; Tripathy, S.S.; Nayak, S.K.; Mohanty, A.K. The influence of fibre treatment on the performance of coir-polyester composites. Compos. Sci. Technol. 2001, 61, 1303-1310. [CrossRef]

60. Johar, N.; Ahmad, I.; Dufresne, A. Extraction, preparation and characterization of cellulose fibres and nanocrystals from rice husk. Ind. Crops Prod. 2012, 37, 93-99. [CrossRef]

61. Revol, J.-F.; Bradford, H.; Giasson, J.; Marchessault, R.H.; Gray, D.G. Helicoidal self-ordering of cellulose microfibrils in aqueous suspension. Int. J. Biol. Macromol. 1992, 14, 170-172. [CrossRef]

62. Rueda, L.; Saralegui, A.; Fernández D’Arlas, B.; Zhou, Q.; Berglund, L.A.; Corcuera, M.A.; Mondragon, I.; Eceiza, A. Cellulose nanocrystals/polyurethane nanocomposites. Study from the viewpoint of microphase separated structure. Carbohydr. Polym. 2013, 92, 751-757. [CrossRef]

63. Ramires, E.; Dufresne, A. A review of cellulose nanocrystals and nanocomposites. TAPPI J. 2011, 10, 9-16.

64. Eichhorn, S.J. Cellulose nanowhiskers: promising materials for advanced applications. Soft Matter 2011, 7, 303-315. [CrossRef]

65. Siqueira, G.; Bras, J.; Dufresne, A. Cellulose whiskers versus microfibrils: Influence of the nature of the nanoparticle and its surface functionalization on the thermal and mechanical properties of nanocomposites. Biomacromolecules 2009, 10, 425-432. [CrossRef]

66. Araki, J.; Wada, M.; Kuga, S.; Okano, T. Flow properties of microcrystalline cellulose suspension prepared by acid treatment of native cellulose. Colloids Surf. A Physicochem. Eng. Asp. 1998, 142, 75-82. [CrossRef]

67. Camarero Espinosa, S.; Kuhnt, T.; Foster, E.J.; Weder, C. Isolation of Thermally Stable Cellulose Nanocrystals by Phosphoric Acid Hydrolysis. Biomacromolecules 2013, 14, 1223-1230. [CrossRef]

68. Liu, C.; Li, B.; Du, H.; Lv, D.; Zhang, Y.; Yu, G.; Mu, X.; Peng, H. Properties of nanocellulose isolated from corncob residue using sulfuric acid, formic acid, oxidative and mechanical methods. Carbohydr. Polym. 2016, 151, 716-724. [CrossRef]

69. Bondeson, D.; Mathew, A.; Oksman, K. Optimization of the isolation of nanocrystals from microcrystalline cellulose by acid hydrolysis. Cellulose 2006, 13, 171-180. [CrossRef]

70. Viet, D.; Beck-Candanedo, S.; Gray, D.G. Dispersion of cellulose nanocrystals in polar organic solvents. Cellulose 2007, 14, 109-113. [CrossRef]

71. Wang, N.; Ding, E.; Cheng, R. Thermal degradation behaviors of spherical cellulose nanocrystals with sulfate groups. Polymer (Guildf.) 2007, 48, 3486-3493. [CrossRef]

72. Roman, M.; Winter, W.T. Effect of sulfate groups from sulfuric acid hydrolysis on the thermal degradation behaviour of bacterial cellulose. Biomacromolecules 2004, 1671-1677. [CrossRef]

73. Lin, N.; Dufresne, A. Surface chemistry, morphological analysis and properties of cellulose nanocrystals with gradiented sulfation degrees. Nanoscale 2014, 6, 5384-5393. [CrossRef]

74. Samir, M.A.S.A.; Alloin, F.; Dufresne, A. Review of Recent Research into Cellulosic Whiskers, Their Properties and Their Application in Nanocomposite Field. Biomacromolecules 2005, 6, 612-626. [CrossRef]

75. Chen, Y.; Liu, C.; Chang, P.R.; Cao, X.; Anderson, D.P. Bionanocomposites based on pea starch and cellulose nanowhiskers hydrolyzed from pea hull fibre: Effect of hydrolysis time. Carbohydr. Polym. 2009, 76, 607-615. [CrossRef]

76. Lu, P.; Hsieh, Y.-L. Preparation and characterization of cellulose nanocrystals from rice straw. Carbohydr. Polym. 2012, 87, 564-573. [CrossRef]

77. Eichhorn, S.J.; Dufresne, A.; Aranguren, M.; Marcovich, N.E.; Capadona, J.R.; Rowan, S.J.; Weder, C.; Thielemans, W.; Roman, M.; Renneckar, S.; et al. Review: Current international research into cellulose nanofibres and nanocomposites. J. Mater. Sci. 2010, 45, 1-33. [CrossRef] 
78. Çetin, N.S.; Tingaut, P.; Özmen, N.; Henry, N.; Harper, D.; Dadmun, M.; Sèbe, G. Acetylation of Cellulose Nanowhiskers with Vinyl Acetate under Moderate Conditions. Macromol. Biosci. 2009, 9, 997-1003. [CrossRef]

79. Kargarzadeh, H.; Mariano, M.; Huang, J.; Lin, N.; Ahmad, I.; Dufresne, A.; Thomas, S. Recent developments on nanocellulose reinforced polymer nanocomposites: A review. Polymer (Guildf.) 2017. [CrossRef]

80. Azizi Samir, M.A.S.; Alloin, F.; Sanchez, J.Y.; El Kissi, N.; Dufresne, A. Preparation of Cellulose Whiskers Reinforced Nanocomposites from an Organic Medium Suspension. Macromolecules 2004, 37, 1386-1393. [CrossRef]

81. Ferreira, F.V.; Dufresne, A.; Pinheiro, I.F.; Souza, D.H.S.; Gouveia, R.F.; Mei, L.H.I.; Lona, L.M.F. How do cellulose nanocrystals affect the overall properties of biodegradable polymer nanocomposites: A comprehensive review. Eur. Polym. J. 2018, 108, 274-285. [CrossRef]

82. Eyley, S.; Thielemans, W. Surface modification of cellulose nanocrystals. Nanoscale 2014, 6, 7764-7779. [CrossRef] [PubMed]

83. Tang, J.; Sisler, J.; Grishkewich, N.; Tam, K.C. Functionalization of cellulose nanocrystals for advanced applications. J. Colloid Interface Sci. 2017, 494, 397-409. [CrossRef] [PubMed]

84. Habibi, Y. Key advances in the chemical modification of nanocelluloses. Chem. Soc. Rev. 2014, 43, 1519-1542. [CrossRef] [PubMed]

85. Cherian, B.M.; Leao, A.L.; de Souza, S.F.; Thomas, S.; Pothan, L.A.; Kottaisamy, M. Cellulose Nanocomposites for High-Performance Applications. In Cellulose Fibers: Bio- and Nano-Polymer Composites; Springer: Berlin/Heidelberg, Germany, 2011; pp. 539-587.

86. Souza, S.F.; Ferreira, M.; Sain, M.; Ferreira, M.Z.; Pupo, H.F.; Cherian, B.M.; Leão, A.L. The use of curaua fibers as reinforcements in composites. In Biofiber Reinforcements in Composite Materials; Elsevier: Amsterdam, The Netherlands, 2015; pp. 700-720.

87. Siqueira, G.; Bras, J.; Follain, N.; Belbekhouche, S.; Marais, S.; Dufresne, A. Thermal and mechanical properties of bio-nanocomposites reinforced by Luffa cylindrica cellulose nanocrystals. Carbohydr. Polym. 2013, 91, 711-717. [CrossRef] [PubMed]

88. Souza, S.F.; Leão, A.L.; Cai, J.H.; Wu, C.; Sain, M.; Cherian, B.M. Nanocellulose from Curava Fibers and their Nanocomposites. Mol. Cryst. Liq. Cryst. 2010, 522, 42/[342]-52/[352]. [CrossRef]

89. Nechyporchuk, O.; Belgacem, M.N.; Bras, J. Production of cellulose nanofibrils: A review of recent advances. Ind. Crops Prod. 2016, 93, 2-25. [CrossRef]

90. Pääkkö, M.; Ankerfors, M.; Kosonen, H.; Nykänen, A.; Ahola, S.; Österberg, M.; Ruokolainen, J.; Laine, J.; Larsson, P.T.; Ikkala, O.; et al. Enzymatic Hydrolysis Combined with Mechanical Shearing and High-Pressure Homogenization for Nanoscale Cellulose Fibrils and Strong Gels. Biomacromolecules 2007, 8, 1934-1941. [CrossRef]

91. Brinchi, L.; Cotana, F.; Fortunati, E.; Kenny, J.M. Production of nanocrystalline cellulose from lignocellulosic biomass: Technology and applications. Carbohydr. Polym. 2013, 94, 154-169. [CrossRef]

92. Mariano, M.; Hantao, L.W.; da Silva Bernardes, J.; Strauss, M. Microstructural characterization of nanocellulose foams prepared in the presence of cationic surfactants. Carbohydr. Polym. 2018, 195, 153-162. [CrossRef]

93. De France, K.J.; Hoare, T.; Cranston, E.D. Review of Hydrogels and Aerogels Containing Nanocellulose. Chem. Mater. 2017, 29, 4609-4631. [CrossRef]

94. Kalia, S.; Boufi, S.; Celli, A.; Kango, S. Nanofibrillated cellulose: Surface modification and potential applications. Colloid Polym. Sci. 2014, 292, 5-31. [CrossRef]

95. Souza, S.F.; Leao, A.L.; Lombello, C.B.; Sain, M.; Ferreira, M. Cytotoxicity studies of membranes made with cellulose nanofibers from fique macrofibers. J. Mater. Sci. 2017, 52, 2581-2590. [CrossRef]

96. Özgür Seydibeyoğlu, M.; Oksman, K. Novel nanocomposites based on polyurethane and micro fibrillated cellulose. Compos. Sci. Technol. 2008, 68, 908-914. [CrossRef]

97. Xu, X.; Liu, F.; Jiang, L.; Zhu, J.Y.; Haagenson, D.; Wiesenborn, D.P. Cellulose Nanocrystals vs. Cellulose Nanofibrils: A Comparative Study on Their Microstructures and Effects as Polymer Reinforcing Agents. ACS Appl. Mater. Interfaces 2013, 5, 2999-3009. [CrossRef] [PubMed]

98. Lin, N.; Gèze, A.; Wouessidjewe, D.; Huang, J.; Dufresne, A. Biocompatible Double-Membrane Hydrogels from Cationic Cellulose Nanocrystals and Anionic Alginate as Complexing Drugs Codelivery. ACS Appl. Mater. Interfaces 2016, 8, 6880-6889. [CrossRef] [PubMed] 
99. Missoum, K.; Belgacem, M.N.; Bras, J. Nanofibrillated cellulose surface modification: A review. Materials (Basel) 2013, 6, 1745-1766. [CrossRef] [PubMed]

100. Abdul Khalil, H.P.S.; Davoudpour, Y.; Islam, M.N.; Mustapha, A.; Sudesh, K.; Dungani, R.; Jawaid, M. Production and modification of nanofibrillated cellulose using various mechanical processes: A review. Carbohydr. Polym. 2014, 99, 649-665. [CrossRef] [PubMed]

101. Moberg, T.; Sahlin, K.; Yao, K.; Geng, S.; Westman, G.; Zhou, Q.; Oksman, K.; Rigdahl, M. Rheological properties of nanocellulose suspensions: effects of fibril/particle dimensions and surface characteristics. Cellulose 2017, 24, 2499-2510. [CrossRef]

102. Abe, K.; Yano, H. Formation of hydrogels from cellulose nanofibers. Carbohydr. Polym. 2011, 85, 733-737. [CrossRef]

103. Abe, K.; Yano, H. Cellulose nanofiber-based hydrogels with high mechanical strength. Cellulose 2012, 19, 1907-1912. [CrossRef]

104. Leitner, J.; Hinterstoisser, B.; Wastyn, M.; Keckes, J.; Gindl, W. Sugar beet cellulose nanofibril-reinforced composites. Cellulose 2007, 14, 419-425. [CrossRef]

105. Ferreira, F.V.; Menezes, B.R.C.; Franceschi, W.; Ferreira, E.V.; Lozano, K.; Cividanes, L.S.; Coutinho, A.R.; Thim, G.P. Influence of carbon nanotube concentration and sonication temperature on mechanical properties of HDPE/CNT nanocomposites. Fuller. Nanotub. Carbon Nanostruct. 2017, 25, 531-539. [CrossRef]

106. Ferreira, F.V.; Francisco, W.; Menezes, B.R.C.; Brito, F.S.; Coutinho, A.S.; Cividanes, L.S.; Coutinho, A.R.; Thim, G.P. Correlation of surface treatment, dispersion and mechanical properties of HDPE/CNT nanocomposites. Appl. Surf. Sci. 2016, 389, 921-929. [CrossRef]

107. Ferreira, F.V.; Brito, F.S.; Franceschi, W.; Simonetti, E.A.N.; Cividanes, L.S.; Chipara, M.; Lozano, K. Functionalized graphene oxide as reinforcement in epoxy based nanocomposites. Surf. Interfaces 2018, 10, 100-109. [CrossRef]

108. Ferreira, F.V.; Franceschi, W.; Menezes, B.R.C.; Biagioni, A.F.; Coutinho, A.R.; Cividanes, L.S. Synthesis, Characterization, and Applications of Carbon Nanotubes. In Carbon-Based Nanofillers and Their Rubber Nanocomposites, 1st ed.; Elsevier: Amsterdam, The Netherlands, 2019; pp. 1-45.

109. Burakowski, L.; Rezende, M.C. Modificação da rugosidade de fibras de carbono por método químico para aplicação em compósitos poliméricos. Polímeros 2001, 11, 51-57. [CrossRef]

110. Ferreira, F.; Mariano, M.; Pinheiro, I.; Cazalini, E.; Souza, D.; Lepesqueur, L.; Koga-Ito, C.; Gouveia, R.; Lona, L. Cellulose nanocrystal-based poly(butylene adipate-co-terephthalate) nanocomposites covered with antimicrobial silver thin films. Polym. Eng. Sci. 2019, 59, E356-E365. [CrossRef]

111. Ferreira, F.V.; Franceschi, W.; Menezes, B.R.C.; Brito, F.S.; Lozano, K.; Coutinho, A.R.; Cividanes, L.S.; Thim, G.P. Dodecylamine functionalization of carbon nanotubes to improve dispersion, thermal and mechanical properties of polyethylene based nanocomposites. Appl. Surf. Sci. 2017, 410, 267-277. [CrossRef]

112. Ferreira, F.V.; Francisco, W.; De Menezes, B.R.C.; Cividanes, L.S.; Coutinho, A.D.R.; Thim, G.P. Carbon nanotube functionalized with dodecylamine for the effective dispersion in solvents. Appl. Surf. Sci. 2015, 357, 2154-2159. [CrossRef]

113. Ferreira, F.V.; Cividanes, L.D.S.; Brito, F.S.; de Menezes, B.R.C.; Franceschi, W.; Nunes Simonetti, E.A.; Thim, G.P. Functionalizing Graphene and Carbon Nanotubes: A Review; SpringerBriefs in Applied Sciences and Technology; Springer International Publishing: Cham, Switzerland, 2016; ISBN 978-3-319-35109-4.

114. Ferreira, F.V.; Cividanes, L.D.S.; Brito, F.S.; de Menezes, B.R.C.; Franceschi, W.; Simonetti, E.A.N.; Thim, G.P. Functionalization of Graphene and Applications. In Functionalizing Graphene and Carbon Nanotubes; Springer International Publishing: Cham, Switzerland, 2016; pp. 1-29.

115. Ferreira, F.V.; Cividanes, L.S.; Brito, F.S.; de Menezes, B.R.C.; Franceschi, W.; Simonetti, E.A.N.; Thim, G.P. Functionalization of Carbon Nanotube and Applications. In Functionalizing Graphene and Carbon Nanotubes; SpringerBriefs in Applied Sciences and Technology; Springer: Cham, Switzerland, 2016.

116. Mariano, M.; El Kissi, N.; Dufresne, A. Cellulose nanocrystals and related nanocomposites: review of some properties and challenges. J Polym Sci B. 2014, 52, 791-806. [CrossRef]

117. Oksman, K.; Aitomäki, Y.; Mathew, A.P.; Siqueira, G.; Zhou, Q.; Butylina, S.; Tanpichai, S.; Zhou, X.; Hooshmand, S. Review of the recent developments in cellulose nanocomposite processing. Compos. Part A Appl. Sci. Manuf. 2016, 83, 2-18. [CrossRef]

118. Dufresne, A. Processing of polymer nanocomposites reinforced with cellulose nanocrystals: A challenge. Int. Polym. Process. 2012, 27, 557-564. [CrossRef] 
119. Siqueira, G.; Bras, J.; Dufresne, A. Cellulosic bionanocomposites: A review of preparation, properties and applications. Polymers (Basel) 2010, 2, 728-765. [CrossRef]

120. Wang, C.; Cai, L.; Shi, S.Q.; Wang, G.; Cheng, H.; Zhang, S. Thermal and flammable properties of bamboo pulp fiber/high-density polyethylene composites: Influence of preparation technology, nano calcium carbonate and fiber content. Renew. Energy 2019, 134, 436-445. [CrossRef]

121. Tan, C.; Peng, J.; Lin, W.; Xing, Y.; Xu, K.; Wu, J.; Chen, M. Role of surface modification and mechanical orientation on property enhancement of cellulose nanocrystals/polymer nanocomposites. Eur. Polym. J. 2015, 62, 186-197. [CrossRef]

122. Ferreira, F.V.; Cividanes, L.S.; Brito, F.S.; de Menezes, B.R.C.; Franceschi, W.; Simonetti, E.A.N.; Thim, G.P. Functionalizing of Graphene and Applications: Review, 1st ed.; Cividanes, L.D.S., Thim, G.P., Eds.; Springer: Berlin/Heidelberg, Germany, 2016; ISBN 9783319351094.

123. Pöllänen, M.; Pirinen, S.; Suvanto, M.; Pakkanen, T.T. Influence of carbon nanotube-polymeric compatibilizer masterbatches on morphological, thermal, mechanical, and tribological properties of polyethylene. Compos. Sci. Technol. 2011, 71, 1353-1360. [CrossRef]

124. Gardner, D.J.; Oporto, G.S.; Mills, R.; Samir, M.A.S.A. Adhesion and Surface Issues in Cellulose and Nanocellulose. J. Adhes. Sci. Technol. 2008, 22, 545-567. [CrossRef]

125. Tang, W.; Santare, M.H.; Advani, S.G. Melt processing and mechanical property characterization of multi-walled carbon nanotube / high density polyethylene ( MWNT / HDPE ) composite films. Carbon N. Y. 2003, 41, 2779-2785. [CrossRef]

126. Pinheiro, I.F.; Ferreira, F.V.; Souza, D.H.S.; Gouveia, R.F.; Lona, L.M.F.; Morales, A.R.; Mei, L.H.I. Mechanical, rheological and degradation properties of PBAT nanocomposites reinforced by functionalized cellulose nanocrystals. Eur. Polym. J. 2017, 97, 356-365. [CrossRef]

127. Mokhothu, T.H.; John, M.J. Review on hygroscopic aging of cellulose fibres and their biocomposites. Carbohydr. Polym. 2015, 131, 337-354. [CrossRef] [PubMed]

128. Sreekala, M.S.; Thomas, S. Effect of fibre surface modification on water-sorption characteristics of oil palm fibres. Compos. Sci. Technol. 2003, 63, 861-869. [CrossRef]

129. Pinheiro, I.F.; Ferreira, F.V.; Alves, G.F.; Rodolfo, A.; Morales, A.R.; Mei, L.H.I. Biodegradable PBAT-Based Nanocomposites Reinforced with Functionalized Cellulose Nanocrystals from Pseudobombax munguba: Rheological, Thermal, Mechanical and Biodegradability Properties. J. Polym. Environ. 2019, 27, 757-766. [CrossRef]

130. Pinheiro, I.F.; Morales, A.R.; Mei, L.H. Polymeric biocomposites of poly (butylene adipate-co-terephthalate) reinforced with natural Munguba fibers. Cellulose 2014, 21, 4381-4391. [CrossRef]

131. Ferreira, F.V.; Trindade, G.N.; Lona, L.M.F.; Bernardes, J.S.; Gouveia, R.F. LDPE-based composites reinforced with surface modified cellulose fibres: 3D morphological and morphometrical analyses to understand the improved mechanical performance. Eur. Polym. J. 2019, in press. [CrossRef]

132. Wang, Q.; Xiao, S.; Shi, S.Q.; Cai, L. Effect of light-delignification on mechanical, hydrophobic, and thermal properties of high-strength molded fiber materials. Sci. Rep. 2018, 8, 955. [CrossRef]

133. Mukherjee, T.; Czaka, M.; Kao, N.; Gupta, R.K.; Choi, H.J.; Bhattacharya, S. Dispersion study of nanofibrillated cellulose based poly(butylene adipate-co-terephthalate) composites. Carbohydr. Polym. 2014, 102, 537-542. [CrossRef]

134. Boldizar, A.; Klason, C.; Kubát, J.; Näslund, P.; Sáha, P. Prehydrolyzed Cellulose as Reinforcing Filler for Thermoplastics. Int. J. Polym. Mater. 1987, 11, 229-262. [CrossRef]

135. Aranguren, M.I.; Marcovich, N.E.; Salgueiro, W.; Somoza, A. Effect of the nano-cellulose content on the properties of reinforced polyurethanes. A study using mechanical tests and positron anihilation spectroscopy. Polym. Test. 2013, 32, 115-122. [CrossRef]

136. Spinella, S.; Lo Re, G.; Liu, B.; Dorgan, J.; Habibi, Y.; Leclère, P.; Raquez, J.-M.; Dubois, P.; Gross, R.A. Polylactide/cellulose nanocrystal nanocomposites: Efficient routes for nanofiber modification and effects of nanofiber chemistry on PLA reinforcement. Polymer (Guildf.) 2015, 65, 9-17. [CrossRef]

137. Morelli, C.L.; Belgacem, M.N.; Branciforti, M.C.; Bretas, R.E.S.; Crisci, A.; Bras, J. Supramolecular aromatic interactions to enhance biodegradable film properties through incorporation of functionalized cellulose nanocrystals. Compos. Part A Appl. Sci. Manuf. 2016, 83, 80-88. [CrossRef]

138. Oliver-Borrachero, B.; Sánchez-Caballero, S.; Fenollar, O.; Sellés, M.A. Natural-Fiber-Reinforced Polymer Composites for Automotive Parts Manufacturing. Key Eng. Mater. 2019, 793, 9-16. [CrossRef] 
139. Abu Bakar, N.; Sultan, M.T.H.; Azni, M.E.; Ariffin, A.H. Investigation of the mechanical properties of Napier-grass-reinforced composites for the aerospace industry. In Durability and Life Prediction in Biocomposites, Fibre-Reinforced Composites and Hybrid Composites; Elsevier: Amsterdam, The Netherlands, 2019; pp. 321-334.

140. Battegazzore, D.; Abt, T.; Maspoch, M.L.; Frache, A. Multilayer cotton fabric bio-composites based on PLA and PHB copolymer for industrial load carrying applications. Compos. Part B Eng. 2019. [CrossRef]

141. Mochane, M.J.; Mokhena, T.C.; Mokhothu, T.H.; Mtibe, A.; Sadiku, E.R.; Ray, S.S.; Ibrahim, I.D.; Daramola, O.O. Recent progress on natural fiber hybrid composites for advanced applications: A review. Express Polym. Lett. 2019, 13, 159-198. [CrossRef]

142. Jiang, A.; Xi, J.; Wu, H. Effect of surface treatment on the morphology of sisal fibers in sisal/polylactic acid composites. J. Reinf. Plast. Compos. 2012, 31, 621-630. [CrossRef]

143. Bajwa, D.; Bhattacharjee, J. Current Progress, Trends and Challenges in the Application of Biofiber Composites by Automotive Industry. J. Nat. Fibers 2016, 13, 660-669.

144. Herrmann, A.S.; Nickel, J.; Riedel, U. Construction materials based upon biologically renewable resources-from components to finished parts. Polym. Degrad. Stab. 1998, 59, 251-261. [CrossRef]

145. Jayaraman, K. Manufacturing sisal-polypropylene composites with minimum fibre degradation. Compos. Sci. Technol. 2003, 63, 367-374. [CrossRef]

146. Wu, Y.; Xia, C.; Cai, L.; Garcia, A.C.; Shi, S.Q. Development of natural fiber-reinforced composite with comparable mechanical properties and reduced energy consumption and environmental impacts for replacing automotive glass-fiber sheet molding compound. J. Clean. Prod. 2018, 184, 92-100. [CrossRef]

147. Bouzouita, A.; Notta-Cuvier, D.; Raquez, J.-M.; Lauro, F.; Dubois, P. Poly(lactic acid)-Based Materials for Automotive Applications. In Advances in Polymer Scienc; Springer: Berlin/Heidelberg, Germany, 2017; pp. 177-219.

148. Holbery, J.; Houston, D. Natural-fiber-reinforced polymer composites in automotive applications. JOM 2006, 58, 80-86. [CrossRef]

149. Mohanty, A.; Misra, M.; Drzal, L. (Eds.) Natural Fibers, Biopolymers, and Biocomposites; CRC Press: Boca Raton, FL, USA, 2005; ISBN 978-0-8493-1741-5.

150. Koronis, G.; Silva, A.; Fontul, M. Green composites: A review of adequate materials for automotive applications. Compos. Part B Eng. 2013, 44, 120-127. [CrossRef]

151. Stewart, R. Automotive composites offer lighter solutions. Reinf. Plast. 2010, 54, 22-28. [CrossRef]

152. Rawal, S.P. Metal-matrix composites for space applications. JOM 2001, 53, 14-17. [CrossRef]

153. Bismarck, A.; Baltazar-Y-Jimenez, A.; Sarikakis, K. Green Composites as Panacea? Socio-Economic Aspects of Green Materials. Environ. Dev. Sustain. 2006, 8, 445-463. [CrossRef]

154. John, M.; Thomas, S. Biofibres and biocomposites. Carbohydr. Polym. 2008, 71, 343-364. [CrossRef]

155. Naskar, A.K.; Keum, J.K.; Boeman, R.G. Polymer matrix nanocomposites for automotive structural components. Nat. Nanotechnol. 2016, 11, 1026-1030. [CrossRef] [PubMed]

156. Kumar, S.K.; Krishnamoorti, R. Nanocomposites: Structure, Phase Behavior, and Properties. Annu. Rev. Chem. Biomol. Eng. 2010, 1, 37-58. [CrossRef]

157. AL-Oqla, F.M.; Sapuan, S.M. Natural fiber reinforced polymer composites in industrial applications: feasibility of date palm fibers for sustainable automotive industry. J. Clean. Prod. 2014, 66, 347-354. [CrossRef]

158. Ashori, A. Wood-plastic composites as promising green-composites for automotive industries! Bioresour. Technol. 2008, 99, 4661-4667. [CrossRef]

(C) 2019 by the authors. Licensee MDPI, Basel, Switzerland. This article is an open access article distributed under the terms and conditions of the Creative Commons Attribution (CC BY) license (http://creativecommons.org/licenses/by/4.0/). 